\title{
Effects of initial planting density on tree and stand development of planted black spruce up to age 30
}

\author{
by Arthur Groot ${ }^{1 *}$ and Francesco Cortini²
}

\begin{abstract}
The effect of initial planting density on tree and stand development was investigated for a 30 year old black spruce plantation in northeastern Ontario. The data came from upland and transitional peatland sites where black spruce (Picea mariana (Mill.) B.S.P.) was planted at inter-tree spacings ranging between 1.25 and $4.00 \mathrm{~m}$. A modified Chapman-Richards function was fit to observations of top height, total volume, basal area, quadratic mean diameter and cumulative stem mortality in relation to initial planting density, stand age and site quality. With the exception of mortality, the fitted models accounted for most of the variation in the response variables. Total volume and basal area increased strongly with initial planting density, whereas quadratic mean diameter decreased. The results quantify the tradeoff between stand volume and individual tree size to age 30 , which will help forest managers make better decisions about initial planting density for black spruce plantations on similar sites.
\end{abstract}

Key words: black spruce; initial planting density; tree and stand development; top height; stand volume; stand basal area; mortality; site quality

\section{RÉSUMÉ}

Cette étude sest intéressée à leffet de la densité initiale de plantation sur la croissance des arbres et du peuplement dans le cas de plantations dépinette noire de 30 ans située dans le nord-est de l'Ontario. Les données viennent de plantations d'épinette noire (Picea mariana (Mill.) B.S.P.) où les semis étaient plantés à un intervalle de 1,25 à 4,00 $\mathrm{m}$ sur des terres hautes et dans les zones de transition de tourbières. Le modèle modifié de croissance de Chapman-Richards a été adapté pour traiter les données de hauteur maximale, de volume total, de surface terrière, de diamètre moyen quadratique et de mortalité cumulative des tiges en fonction de la densité initiale de plantation, de lâge du peuplement et de la qualité de la station. À l'exception de la mortalité, les modèles modifiés reflétaient bien la majeure partie de la variation des variables mesurées. Le volume total et la surface terrière ont augmenté fortement avec la densité initiale de plantation, tandis que le diamètre moyen quadratique a diminué. Les résultats permettent de quantifier les compromis à faire entre le volume du peuplement et la taille individuelle des arbres âgés de 30 ans, ce qui devrait aider les aménagistes forestiers à prendre les meilleures décisions quant à la densité initiale de plantation pour l'épinette noire sur des stations semblables.

Mots clés : épinette noire, densité initiale de plantation, développement des arbres et du peuplement, hauteur maximale, volume du peuplement, surface terrière du peuplement, mortalité, qualité de station

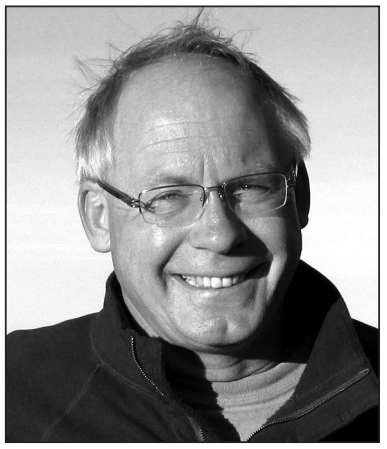

Arthur Groot

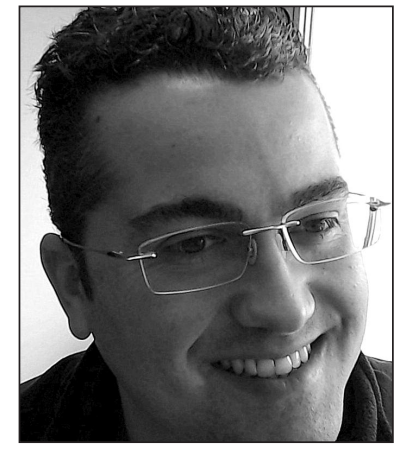

Francesco Cortini

\section{Introduction}

The initial density of tree plantations affects the rate and completeness of site occupation and also the availability of resources for the crop trees; thus the selection of the initial inter-tree planting distance is an important management decision. Low planting densities can result in a loss of stand volume growth through delayed or partial site occupation, whereas high planting densities can negatively affect growth and size of individual trees by reducing the available resources per tree.

Black spruce (Picea mariana (Mill.) B.S.P.) is an important commercial species in the eastern boreal forests of Canada; however, information on the relationships between initial planting density and tree and stand yield is limited. Stand

\footnotetext{
${ }^{1}$ Canadian Wood Fibre Centre, Canadian Forest Service, Natural Resources Canada, 1219 Queen St. E., Sault Ste. Marie, ON, P6A 2E5;

* corresponding author's email: art.groot@gmail.com

${ }^{2}$ Canadian Wood Fibre Centre, Canadian Forest Service, Natural Resources Canada, 506 West Burnside Rd., Victoria, British Columbia V8Z 1M5
} 
density management diagrams can provide an approximation of these relationships, although confirmation from independent initial planting density trials is still required (Newton and Weetman 1994). Higher initial black spruce planting densities have been recommended for more intensive forest management in the boreal forest of Ontario, but the growth and yield implications of these recommendations have not been quantified (Bell et al. 2008).

A literature search identified two studies that have previously examined the effects of initial density on black spruce plantation development. McClain et al. (1994) reported on 37-year-old spruce planted at $1.8 \mathrm{~m}, 2.7 \mathrm{~m}$ and $3.6 \mathrm{~m}$ intertree distance, and Matheson and Stewart (1986) reported on 14-year-old spruce planted at spacing ranging from $1.08 \mathrm{~m}$ to $2.32 \mathrm{~m}$. Both studies were located south of the Boreal Forest Region (Rowe 1972) and indicated that individual tree size increased and stand volume decreased as initial planting density increased.

The objective of this study, located within the Northern Clay Section of the Boreal Forest Region (Rowe 1972), is to examine the effects of initial planting density (i.e., $1.25 \mathrm{~m}$ to $4.0 \mathrm{~m}$ range) on black spruce tree and stand development up to age 30 .

\section{Materials and Methods \\ Site Description and Experimental Layout}

The experiment was established approximately $48 \mathrm{~km}$ southeast of Kapuskasing, Ontario (49 01'north, 82 $09^{\circ}$ ' east). In the summer and fall of 1981, a clear-cut harvest removed the black spruce-dominated and mixedwood stands composed of trembling aspen (Populus tremuloides Michx.), white birch (Betula papyrifera Marsh.), white spruce (Picea glauca (Moench) Voss) and balsam fir (Abies balsamea L.). A prescribed fire was carried out in August 1983, which reduced slash depth by $60 \%$ and reduced the forest floor depth by an average of $3 \mathrm{~cm}$.

The experiment was established on terrain types upland (clayey soil) and transitional peatland $(15 \mathrm{~cm}$ to $40 \mathrm{~cm}$ of organic matter over clayey soil). Post-burn forest ecosystem classification of site types was not possible, but based on the soil and on nearby unburnt stands, site types were likely ES9p (Black Spruce - Larch - Moist Soil - Species Poor) and ES8 (Black Spruce - Feathermoss - Sphagnum - Moist Soil) on the transitional sites and ES7f (Trembling Aspen - White Spruce - White Birch - Fine Soil) on the upland sites (Taylor et al. 2000).

Treatment plots, each 0.64 ha in area, were established in September 1983 with inter-tree square spacings of $1.25 \mathrm{~m}$, $1.50 \mathrm{~m}, 1.75 \mathrm{~m}, 2.00 \mathrm{~m}, 2.50 \mathrm{~m}$ and $3.00 \mathrm{~m}$ each randomly assigned to three plots on each site type. A $4.00 \mathrm{~m}$ spacing was assigned to three plots only on the transitional site type.

Bare-root $1 \frac{1 / 2}{2}+2 \frac{1}{2}$ stock was planted at the prescribed spacings from late September to early October, 1983. The planted seedlings suffered high mortality (averaging 50\%, but highly variable from plot to plot) by mid-summer 1984, possibly because of above-normal air temperatures during April 1984. In 1984, it was decided to abandon the plots with the greatest mortality and carry out fill planting to the planned nominal density on one plot of each initial density on each site type. Fill planting was carried out with $1 \frac{1}{2}+1 \frac{1}{2}$ stock May 27-28, 1985, and again June 10-14, 1986 with 1+2 and G-
$1 \frac{1}{2}$ stock. Control of competing vegetation was carried out periodically with manual (cutting or breaking aspen stems) and herbicide treatments.

The final treatment set comprised nominal spacings (SPAC) of $1.25 \mathrm{~m}, 1.50 \mathrm{~m}, 1.75 \mathrm{~m}, 2.00 \mathrm{~m}, 2.50 \mathrm{~m}$, and $3.00 \mathrm{~m}$ applied to one treatment plot on each site type and a spacing of $4.00 \mathrm{~m}$ applied to one treatment plot on the transitional site type, for a total of 13 treatment plots. Two measurement subplots were established within each treatment plot in fall 1993 and early spring 1994. The size of the subplot varied with the initial density treatment so that each subplot would contain approximately 100 trees.

Each tree within each subplot was tagged and the diameter at breast height $(d b h)$ and the height of each tree was measured in early spring of 1994, 1999, 2001. In the fall of $2003\left(20^{\text {th }}\right.$ year re-measurement) and $2008\left(25^{\text {th }}\right.$ year remeasurement), and in the spring of 2014 ( $30^{\text {th }}$ year re-measurement), the $d b h$ of all tagged trees was measured, but only a subsample of heights ( 25 trees per subplot) was taken.

\section{Statistical Analysis}

For trees aged 20, 25 and 30 years, a non-linear model was used to estimate height of the tagged trees without height measurements (i.e., 75\% of total trees). A power function model was used to fit the existing data to estimate height from dbh by terrain, spacing and age (Stage 1975). For each tree and measurement age (i.e., 10, 15, 17, 20, 25 and 30 years), basal area was calculated as the area of a circle with radius equal to $d b h / 2$ and stem volume was calculated using Honer's volume equation for black spruce (Honer et al. 1983). For a small number (i.e., $0.4 \%$ of total trees) of trees forked below $1.3 \mathrm{~m}$ height, non-linear models of height and $d b h$ in relation to age were developed at the subplot level in order to estimate height and dbh values for the smaller fork that were not recorded during the earlier assessments.

The individual tree data for living trees were used to compute the following variables for each measurement age and subplot: quadratic mean diameter (QMD in $\mathrm{cm}$ ), mean height of the tallest 100 trees per ha at age 10 and age $30\left(H 100_{10}\right.$ and $H 100_{30}$ in $\mathrm{m}$, also termed top height), stand basal area ( $B A$ in $\mathrm{m}^{2} \mathrm{ha}^{-1}$ ), and total volume (VOL in $\mathrm{m}^{3} \mathrm{ha}^{-1}$ ). Cumulative percent mortality (MORT) was also calculated relative to the density at age $10\left(\mathrm{TPH}_{10}\right.$ in stems ha $\left.{ }^{-1}\right)$ by subplot for each subsequent measurement age. $\mathrm{TPH}_{10}$ was used as the measure of initial density since changes in density related to post planting mortality and infilling had stabilized at age 10. Mean stand characteristics at age 30 for the seven spacings are summarized in Table 1.

In an initial step, several candidate models were fit to tree and stand observations over time; the Chapman-Richards function, which has a flexible sigmoidal form (Pienaar and Turnbull 1973), consistently provided lowest residual error. Consequently, it was used as a base model to fit observations of the response variables $H 100, V O L, B A$ and $Q M D$ to stand age $(A G E)$. The base form of the function is:

[1] Response $=a_{0}\left(1-\exp \left(a_{1} A G E\right)\right)^{a_{2}}$

the upper asymptote for the quantity and $a_{1}$ and $a_{2}$ control the shape of the curve. The base Chapman-Richards function was modified to incorporate the effects of initial planting density 
Table 1. Mean age 30 characteristics of the black spruce study (minimum and maximum subplot values in brackets)

\begin{tabular}{|c|c|c|c|c|c|c|c|}
\hline $\begin{array}{l}\text { Nominal } \\
\text { spacing }\end{array}$ & $\begin{array}{l}\text { Number of } \\
\text { subplots }\end{array}$ & $\begin{array}{c}\text { Initial } \\
\text { (age 10) } \\
\text { stand density }\end{array}$ & $\begin{array}{c}\text { Cumulative } \\
\text { mortality }\end{array}$ & Top height & $\begin{array}{l}\text { Quadratic } \\
\text { mean } \\
\text { diameter }\end{array}$ & Basal area & Total volume \\
\hline m & $\#$ & stems ha ${ }^{-1}$ & $\%$ & m & $\mathrm{cm}$ & $\mathbf{m}^{2} \mathbf{h a}^{-1}$ & $m^{3} h a^{-1}$ \\
\hline 1.25 & 4 & $6,016(5,376-6,656)$ & $7.49(3.13-16.30)$ & $10.1(9.5-10.8)$ & $8.3(7.7-8.9)$ & $30.3(29.5-31.8)$ & $119(112-129)$ \\
\hline 1.50 & 4 & $4,411(3,778-4,667)$ & $1.73(0.97-2.78)$ & $9.9(8.8-10.8)$ & $8.8(6.8-10.6)$ & $27.0(16.9-38.2)$ & $110(57-168)$ \\
\hline 1.75 & 4 & $3,037(2,743-3,233)$ & $5.01(2.15-10.74)$ & $10.2(9.9-10.5)$ & $10.1(9.5-10.8)$ & $23.4(17.7-28.3)$ & $98(72-122)$ \\
\hline 2.00 & 4 & $2,388(2,325-2,475)$ & $4.77(1.04-20.75)$ & $10.3(9.5-11.3)$ & $11.1(9.1-13.0)$ & $22.5(13.4-29.7)$ & 99 (51-139) \\
\hline 2.50 & 4 & $1,584(1,504-1,664)$ & $0.76(0.00-2.06)$ & $10.0(9.9-10.1)$ & $12.2(11.2-12.8)$ & $18.2(16.2-20.9)$ & $75(65-90)$ \\
\hline 3.00 & 4 & $1,278(1,089-1,478)$ & $3.45(0.00-8.27)$ & $10.0(9.8-10.3)$ & $13.4(11.9-15.4)$ & $17.3(15.1-19.7)$ & $74(62-87)$ \\
\hline 4.00 & 2 & $619(606-631)$ & $1.98(0.00-3.96)$ & $9.8(9.5-10.0)$ & $12.9(12.1-13.7)$ & $8.0(7.0-9.0)$ & $33(28-38)$ \\
\hline
\end{tabular}

(either $T P H_{10}$ or SPAC) and site quality ( $H 100$ at various ages and TERRAIN, a binary terrain variable, with values of 0 for upland terrain and 1 for transitional terrain). These effects were incorporated by replacing the $a_{0} a_{1}$ or $a_{2}$ parameter with linear functions of $\mathrm{TPH}_{10}$ or $S P A C$ and site quality $\mathrm{H} 100_{30}$. The decision of which parameter to replace and which variable to include in the linear function was made on the basis of the combination that yielded the lowest value of Aikake's Information Criterion (Burnham and Anderson 2002). The subplot was used as the experimental unit, and because repeated measurements on subplots were likely correlated, mixed effects version of the models were fitted. Random effects were included in the estimates of the asymptote of the Chapman-Richards function. A constant correlation structure within subplots was assumed; in other words, for each subplot the random component of the asymptote was constant with time. All analysis was carried out using the R package, nlme (R Core Team 2012).

\section{Top Height}

An initial mixed effects version of the Chapman-Richards function was fitted to top height over age data:

$$
\text { [2] } \begin{aligned}
H 100_{\text {sp,age }} & =\left(a_{0}+\alpha_{0, s p}\right)\left(1-\exp \left(a_{1} A G E\right)\right)^{a_{2}} \\
& +\epsilon_{\text {sp,age }}
\end{aligned}
$$

Where $\alpha_{0, s p}$ is the random effect for $a_{0}$, the function asymptote, associated with subplot $s p$ and $\varepsilon_{\text {sp,age }}$ is the residual error. Correlations of the values $a_{0, s p}$ from eq. 2 with $S P A C, T P H_{10}$, $H 100_{10}, H 100_{30}$ (the latter two variables are the heights of the tallest 100 trees per ha at ages 10 and 30, respectively) were examined to assess the influence of planting density and site index measures on subplot variation in H100 over age patterns.

Eq. 2 was then modified to make the asymptote a linear function of $\mathrm{H}_{100_{30}}$ (eq. 3):

$$
\text { [3] } \begin{aligned}
H 100_{\text {sp,age }} & =\left(a_{0}+\alpha_{0, s p}+b_{0} H 100_{30}\right) \\
& \left(1-\exp \left(a_{1} A G E\right)\right)^{a_{2}}+\epsilon_{\text {sp,age }}
\end{aligned}
$$

\section{Total Volume and Basal Area}

The Chapman-Richards function was modified to incorporate the influence of site quality and initial density on volume and basal area over age patterns. Similar to equation eq. 3 , the asymptote was a linear function of $H 100_{30}$, and was also modified by an exponential function of $\mathrm{TPH}_{10}$ that varied nonlinearly between 1 at high densities and 0 at 0 density. The rate was a linear function of $\mathrm{H}_{100_{30}}$ and $\mathrm{TPH}_{10}$.

[4]

$$
\begin{aligned}
& V O L_{s p, a g e} \text { or } B A_{s p, a g e}=\left(a_{0}+\alpha_{0, s p}+b_{0} H 100_{30}\right) \cdot \\
& \left(1-\exp \left(b_{1} T P H_{10}\right)\right)\left(1-\exp \left(\left(a_{1}+b_{2} H 100_{30}\right.\right.\right. \\
& \left.\left.\left.+b_{3} T P H_{10}\right) A G E\right)\right)^{a_{2}}+\epsilon_{s p, a g e}
\end{aligned}
$$

\section{Quadratic mean diameter}

The function for $Q M D$ was similar to eq. 4, except for the structure of the asymptote modifier. In this case the modifier was an exponential function of $\mathrm{TPH}_{10}$ that varied nonlinearly between 0 at high densities and 1 at 0 density:

[5]

$$
\begin{aligned}
& Q M D_{s p, a g e}=\left(a_{0}+\alpha_{0, s p}+b_{0} H 100_{30}\right) \cdot \\
& \left(\exp \left(b_{1} T P H_{10}\right)\right)\left(1-\exp \left(\left(a_{1}+b_{2} H 100_{30}\right.\right.\right. \\
& \left.\left.\left.+b_{3} T P H_{10}\right) A G E\right)\right)^{a_{2}}+\epsilon_{s p, a g e}
\end{aligned}
$$

\section{Mortality}

Cumulative mortality (\%) was modelled as a negative exponential function of $A G E-10$, so that the cumulative mortality was $0 \%$ at age 10 , the first measurement occasion. The influence of age was modified by TERRAIN and $T P H_{10}$ :

$$
\begin{aligned}
\text { MORT }_{\text {sp,age }} & =100\left(1-\exp \left(\left(\alpha_{1, s p}+b_{2}\right.\right. \text { TERRAIN }\right. \\
& \left.\left.\left.+b_{3} \text { TPH } H_{10}\right)(A G E-10)\right)\right)+\epsilon_{\text {sp,age }}
\end{aligned}
$$

First derivatives of response variables with respect to $A G E$ for the final fitted models (eq. 4-6) were also calculated in order to to provide annual estimates of growth and mortality (Appendix A) $)^{3}$.

\footnotetext{
${ }^{3}$ Appendix $\mathrm{A}$ is available only in the on-line version of this paper
} 


\section{Results \\ Top height}

Values of the random parameter $\alpha_{0, s p}$ in eq. 2 averaged nearly $1 \mathrm{~m}$ greater for upland sites than for transitional sites (Fig. 1) and the values varied considerably within terrain types as well. Estimates of the random parameter $\alpha_{0, s p}$ in eq. 2 were not significantly correlated to $S P A C(\mathrm{r}=-0.224, \mathrm{p}=0.251)$ or to $T_{P H}(\mathrm{r}=0.050, \mathrm{p}=0.801)$; while estimates were highly correlated with $H 100_{10}(\mathrm{r}=0.745, \mathrm{p}<$ $0.001)$ and $H 100_{30}(\mathrm{r}=0.954, \mathrm{p}<0.001)$. Eq. 3 , which incorporated $\mathrm{H}_{100_{30}}$ as a predictor variable, provided a good description of observed $\mathrm{H} 100$ over Age patterns (Fig. 2, Table 2).

\section{Total stand volume}

Total volume was strongly affected by spacing, with modelled volumes for a $1.25 \mathrm{~m}$ spacing at age 30 $\left(118 \mathrm{~m}^{3} \mathrm{ha}^{-1}\right)$ more than twice as large as for a 4.00 m spacing $\left(47 \mathrm{~m}^{3} \mathrm{ha}^{-1}\right)$ (Fig 3a). Volume growth peaked at age 25 for narrow spacings, while it continued to increase for wider spacings (Fig. 3b).

\section{Basal area}

Basal area was also strongly affected by spacing with modelled values for a $1.25 \mathrm{~m}$ spacing at age 30 $\left(27 \mathrm{~m}^{2} \mathrm{ha}^{-1}\right)$ nearly three times as large as for a 4.00 $\mathrm{m}$ spacing $\left(10 \mathrm{~m}^{2} \mathrm{ha}^{-1}\right)$ (Fig $\left.4 \mathrm{a}\right)$. Basal area growth peaked earlier at narrow spacing, and by age 30 the modelled basal area growth of a $1.25 \mathrm{~m}$ spacing was less than that of a 1.50 or $1.75 \mathrm{~m}$ spacing (Fig. 4b).

\section{Quadratic mean diameter}

Diameter was also strongly affected by spacing with modelled values for a $1.25 \mathrm{~m}$ spacing at age 30 $(7.6 \mathrm{~cm}$ ) less than $60 \%$ of the value for a $4.00 \mathrm{~m}$ spacing $(12.9 \mathrm{~cm})$ (Fig 5a). Diameter growth peaked at age 15 for all spacings, and by age $30 \mathrm{had}$ declined to about one-third or less of the age 15 values (Fig. 5b). As with total volume (Fig. $3 \mathrm{c}$ and 3d, Table 2) and basal area (Fig. 4c and 4d, Table 2) , the model fitted the $Q M D$ observations well, particularly when the estimates of the random subplot effects were incorporated (Fig. $5 c$ and 5 d, Table 2).

\section{Cumulative mortality}

Cumulative mortality was also strongly affected by spacing with modelled values for a $1.25 \mathrm{~m}$ spacing at age $30(7.1 \%)$ more than twice the value for a $4.00 \mathrm{~m}$ spacing (3.3\%) (Fig 6a). The annual rate of mortality was nearly constant with age (Fig. 6b). The model fit for cumulative mortality was poorer than for the other response variables (Fig. $6 \mathrm{c}$ and 6d, Table 2).

\section{Discussion}

The main value of this study is the quantification in model form of the effects of initial planting density and site quality or site type over time. As expected, initial density had a strong influence on patterns of $V O L, B A, Q M D$ and, to a lesser extent, MORT in relation to stand age. The Chapman-

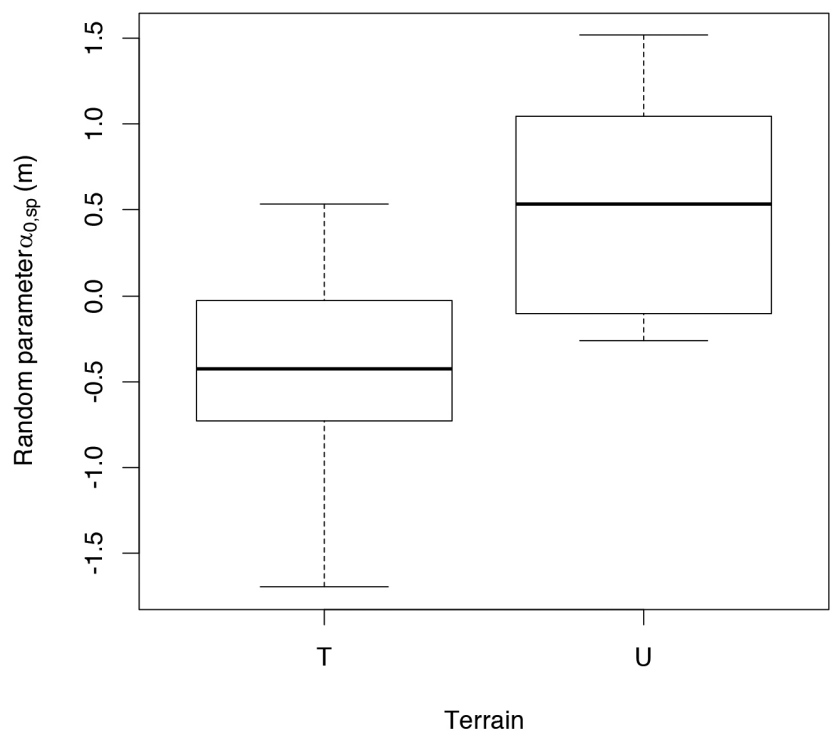

Fig. 1. Box and whisker plot of the random parameter $\alpha_{0, s p}$ from eq. 1 for transitional $(T)$ and upland (U) sites.

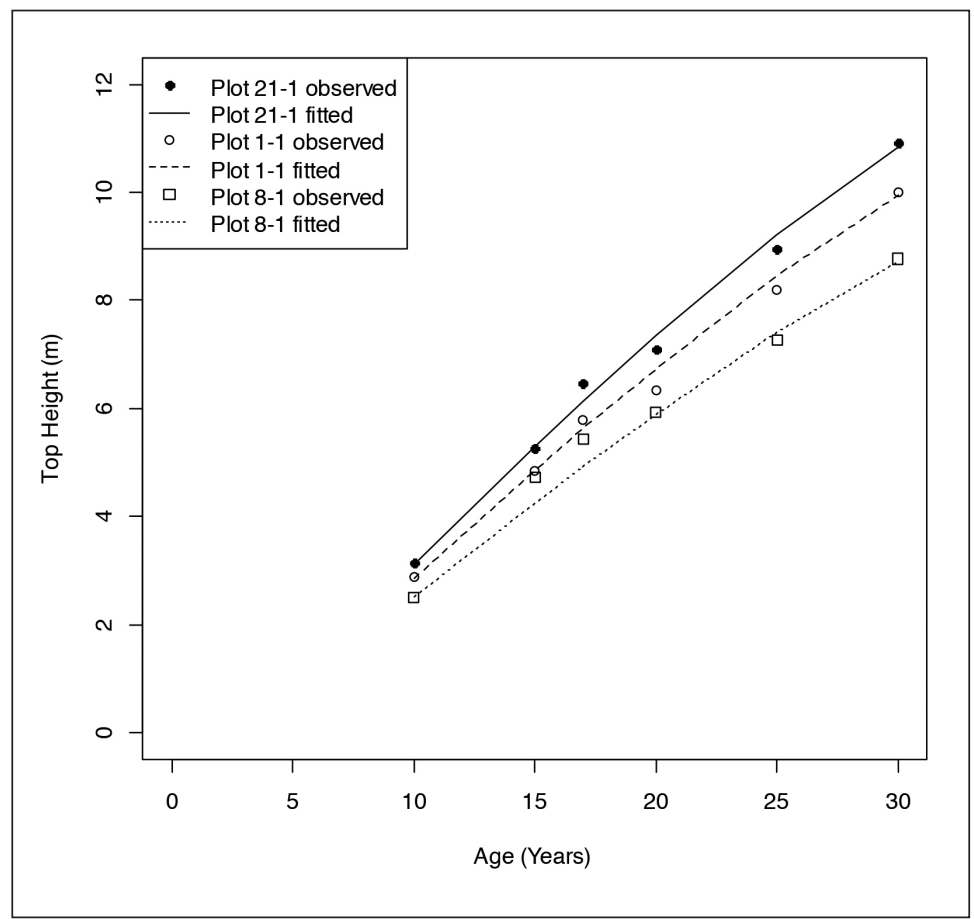

Fig. 2. Observed and fitted (eq. 3) values of $H 100$ over age for the three subplots with the highest, median and lowest values of $H 100$ at age 30 . Plots 21 and 1 are on upland terrain, and plot 8 is on transitional peatland terrain.

Richards function was well-suited for modelling the effects of initial planting density and site quality on stand volume, basal area and quadratic mean diameter in relation to stand age. The fixed effects portion of the models accounted for $94 \%$ or more of the variation in the response variables, with the 
Table 2. Parameter estimates (with standard errors in brackets) and fit statistics for eqs 2-6 describing black spruce response to initial density, site quality or site type, and age. Units for the residual error terms (RMSE) are the same as the units for the response variables.

\begin{tabular}{|c|c|c|c|c|c|c|}
\hline \multirow[b]{2}{*}{ Parameter } & \multirow{2}{*}{$\begin{array}{l}\text { Eq. } 2 \\
\begin{array}{c}H 100 \\
(\mathrm{~m})\end{array}\end{array}$} & \multirow{2}{*}{$\begin{array}{l}\text { Eq. } 3 \\
\begin{array}{c}H 100 \\
(\mathrm{~m})\end{array}\end{array}$} & \multicolumn{2}{|c|}{ Eq. 4} & \multirow{2}{*}{$\begin{array}{l}\text { Eq. } 5 \\
Q M D \\
(\mathrm{~cm})\end{array}$} & \multirow{2}{*}{$\begin{array}{c}\text { Eq. } 6 \\
\text { MORT } \\
(\%)\end{array}$} \\
\hline & & & $\begin{array}{c}V O L \\
\left(\mathrm{~m}^{3} \mathrm{ha}^{-1}\right)\end{array}$ & $\begin{array}{c}B A \\
\left(\mathrm{~m}^{2} \mathrm{ha}^{-1}\right)\end{array}$ & & \\
\hline$a_{0}$ & $\begin{array}{l}16.24 \\
(0.77)\end{array}$ & n.s. & $\begin{array}{l}-958.2 \\
(167.6)\end{array}$ & $\begin{array}{c}-87.63 \\
(20.19)\end{array}$ & n.s. & - \\
\hline$b_{0}$ & - & $\begin{array}{c}1.671 \\
(0.087)\end{array}$ & $\begin{array}{c}119.8 \\
(17.37)\end{array}$ & $\begin{array}{c}12.23 \\
(2.028)\end{array}$ & $\begin{array}{c}1.629 \\
(0.0613)\end{array}$ & - \\
\hline$b_{1}$ & - & - & $\begin{array}{c}-1.59 \mathrm{E}-03 \\
(4.06 \mathrm{E}-04)\end{array}$ & $\begin{array}{c}-9.63 \mathrm{E}-04 \\
(1.49 \mathrm{E}-04)\end{array}$ & $\begin{array}{c}-1.052 \mathrm{E}-04 \\
(1.07 \mathrm{E}-05)\end{array}$ & - \\
\hline$a_{1}$ & $\begin{array}{c}-0.04794 \\
(0.00393)\end{array}$ & $\begin{array}{c}-0.04514 \\
(0.00403)\end{array}$ & $\begin{array}{c}-0.06243 \\
(0.00444)\end{array}$ & $\begin{array}{c}-0.09712 \\
(0.00533)\end{array}$ & $\begin{array}{c}-0.1171 \\
(0.00369)\end{array}$ & n.s. \\
\hline$b_{2}$ & - & - & n.s. & n.s. & n.s. & $\begin{array}{c}-1.483 \mathrm{E}-03 \\
(6.18 \mathrm{E}-04\end{array}$ \\
\hline$b_{3}$ & - & - & $\begin{array}{c}-2.74 \mathrm{E}-06 \\
(3.41 \mathrm{E}-07)\end{array}$ & $\begin{array}{c}-3.52 \mathrm{E}-06 \\
(4.42 \mathrm{E}-07)\end{array}$ & $\begin{array}{c}-3.26 \mathrm{E}-06 \\
(4.68 \mathrm{E}-07)\end{array}$ & $\begin{array}{r}-3.431 \mathrm{E}-07 \\
(1.33 \mathrm{E}-07)\end{array}$ \\
\hline$a_{2}$ & $\begin{array}{c}1.801 \\
(0.083)\end{array}$ & $\begin{array}{c}1.746 \\
(0.0823)\end{array}$ & $\begin{array}{c}7.440 \\
(0.4821)\end{array}$ & $\begin{array}{c}8.554 \\
(0.6557)\end{array}$ & $\begin{array}{c}5.837 \\
(0.2835)\end{array}$ & - \\
\hline$\sigma\left(a_{0}\right)$ & 0.7987 & 0.1598 & 39.7 & 5.217 & 1.437 & - \\
\hline$\sigma\left(a_{1}\right)$ & - & - & - & - & - & 0.00179 \\
\hline Residual Error & 0.2125 & 0.2116 & 2.237 & 0.682 & 0.2551 & 0.8116 \\
\hline${ }^{*}$ pseudo-R ${ }^{2}$ Fixed & 0.971 & 0.991 & 0.948 & 0.940 & 0.953 & 0.263 \\
\hline pseudo-R ${ }^{2}$ Mixed & 0.992 & 0.991 & 0.996 & 0.993 & 0.994 & 0.908 \\
\hline
\end{tabular}

- parameter not used in the model

n.s. parameter dropped from model because not significant $(p>0.05)$

$$
\text { *Pseudo }-R^{2}=1-\frac{\sum_{i=1}^{n}\left(y_{i}-\hat{y}_{i}\right)^{2}}{\sum_{i=1}^{n}\left(y_{i}-\bar{y}\right)^{2}}
$$

where $y_{i}$-observed values; $\hat{y}_{i}-$ predicted values; $\bar{y}_{i}$ average; $n$-sample size.

mixed effects version of the models accounting for virtually $100 \%$ of the observed variation. The mixed effects analysis provides better estimates of the value and significance of the model parameters because it takes into account the correlation of observations within subplots (Hall and Bailey 2001). The model fit for cumulative mortality was much lower compared to the other response variables, likely related to the greater variability inherent in tree mortality and also because of the small sample size within subplots.

Before the onset of inter-tree competition for growth resources, $V O L$ and $B A$ for a given stand age simply increase linearly with stand density. The VOL and $B A$ model predictions presented a clear nonlinear response to stand density by age 15 , however, indicating the early onset of competition. At age 25 and 30, modelled values of $B A$ growth differed little among spacings in the range from 1.25 to $2.0 \mathrm{~m}$, suggesting a parallel or possibly convergent future $B A$ development pattern. Modelled values of $V O L$ growth for the $1.25 \mathrm{~m}$ to $2.0 \mathrm{~m}$ spacing were starting to show convergence at age 30 , suggesting that future $V O L$ development at higher initial planting densities may also become parallel or convergent. The tendency to convergent $V O L$ and $B A$ growth over a range of initial spacing is consistent with the long-standing hypothesis in forest production theory that stand growth is essentially constant over a wide range of stem densities (Skovsgaard and Vanclay 2008, Pretzsch 2009). 


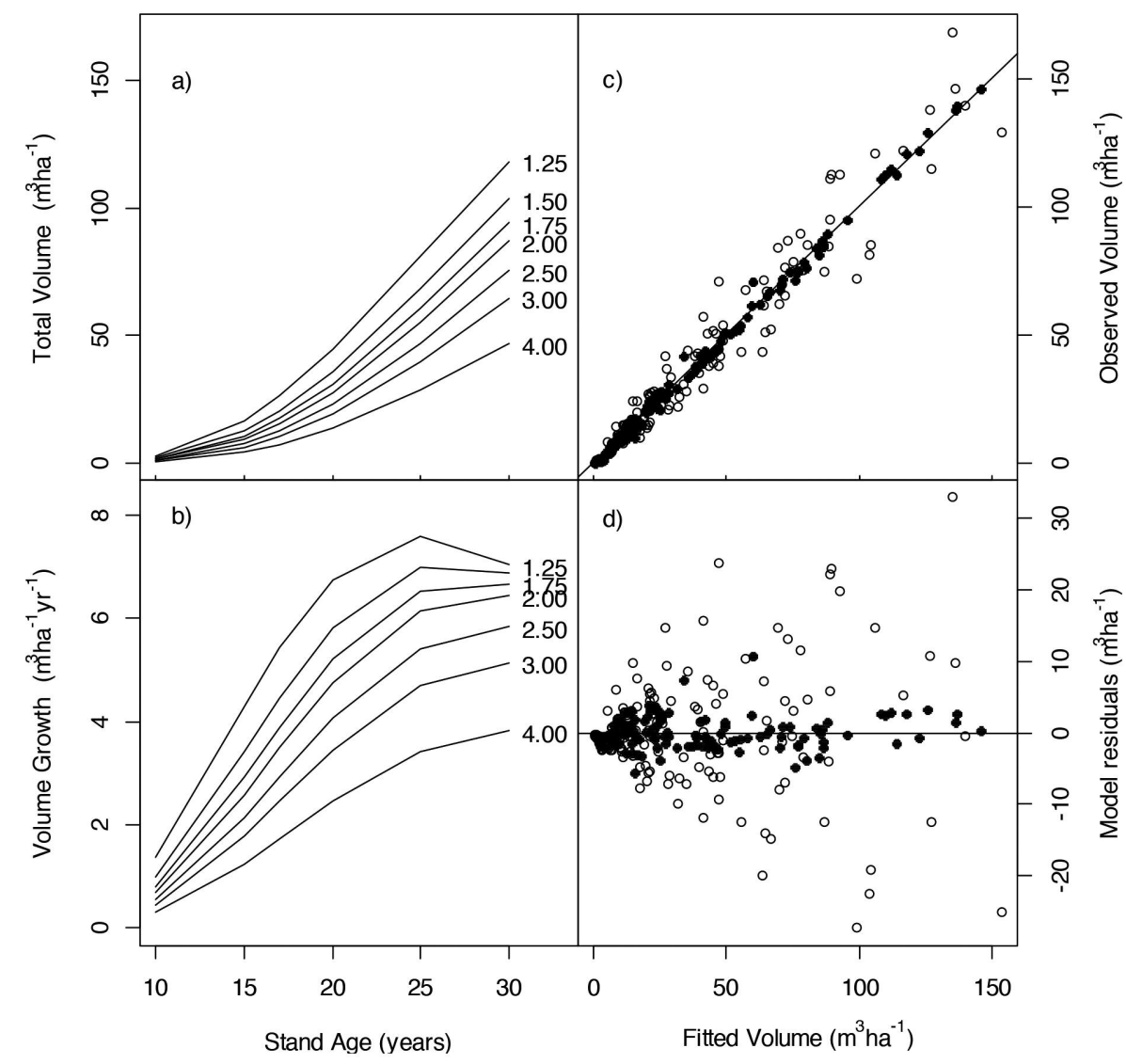

Fig. 3. Modelled total volume (a) using eq. 4 and volume growth (b) using eq. A1 (Appendix A) over age for initial spacings from 1.25 to $4.00 \mathrm{~m}$ with $\alpha_{0, s p}=0$ and $\mathrm{H1OO}_{30}=10.0 \mathrm{~m}$. Observed volume (c) and model residuals (d) vs fitted volume for mixed effects with estimated random effects $\left(\alpha_{0, s p}\right.$ ) for subplots (closed symbols) and with random effects set to 0 (open symbols).

The asymptotic values of stand volume, basal area and quadratic mean diameter all depend on both initial density and site quality. For stand volume, $95 \%$ of the fully stocked asymptote is attained with intial densities above about 2000 stems ha ${ }^{-1}$ and for basal area the corresponding value is 3000 stems ha ${ }^{-1}$. Consequently, this analysis suggests that full site occupation will not be achieved when initial densities are below 2000 stems ha $^{-1}$. For a top height of $10 \mathrm{~m}$ at age 30 , the fully stocked asymptotes for total volume and basal area are $240 \mathrm{~m}^{3} \mathrm{ha}^{-1}$ and $34 \mathrm{~m}^{2} \mathrm{ha}^{-1}$, respectively. These values are similar to age 100 natural stand normal yield table values for site class 2 black spruce (Plonski 1974).

The early onset of competition was even clearer in the modelled QMD growth patterns, with suppression of $Q M D$ growth already apparent at high stand densities at age 10 and pronounced at age 15. The asymptotic values of $Q M D$ also depend on both initial density and site quality. For $\mathrm{H}_{100_{30}}$, the asymptotic values of $Q M D$ range from $15.3 \mathrm{~cm}$ for $T P H_{10}$ $=625 \mathrm{ha}^{-1}$ to $8.3 \mathrm{~cm}$ for $\mathrm{TPH}_{10}=6400 \mathrm{ha}^{-1}$. The low asymptotic values of $Q M D$ that result from high $T P H_{10}$ are unattractive from a forest management perspective, although it should be noted that the model asymptotes do not take into account the likely effect of increased future mortality on tree and stand development. Natural, fully stocked black spruce stands establish at greater stand densities (ca. 10,000 ha-1) than the highest density planted in this experiment (Plonski 1974). These natural stands undergo intense self-thinning through their development, and mean tree diameters are considerably greater than the modelled asymptotic values of $Q M D$ that result from high $T P H_{10}$

Although the influence of intial stand density on cumulative mortality was statistically significant, the fixed effects accounted for only small proportion of the variance. This was not surprising, since tree mortality has historically been a poorly understood component of stand development and has posed modelling challenges (Monserud and Sterba 1999). Mortality is influenced by a number of biotic (competition, insects, disease) and abiotic (drought, frost) factors and consequently can be highly variable. The substantial random effects in this experiment indicated large subplot-to-subplot variation in mortality that could not be accounted for by initial planting density or terrain. The cumulative mortality to 


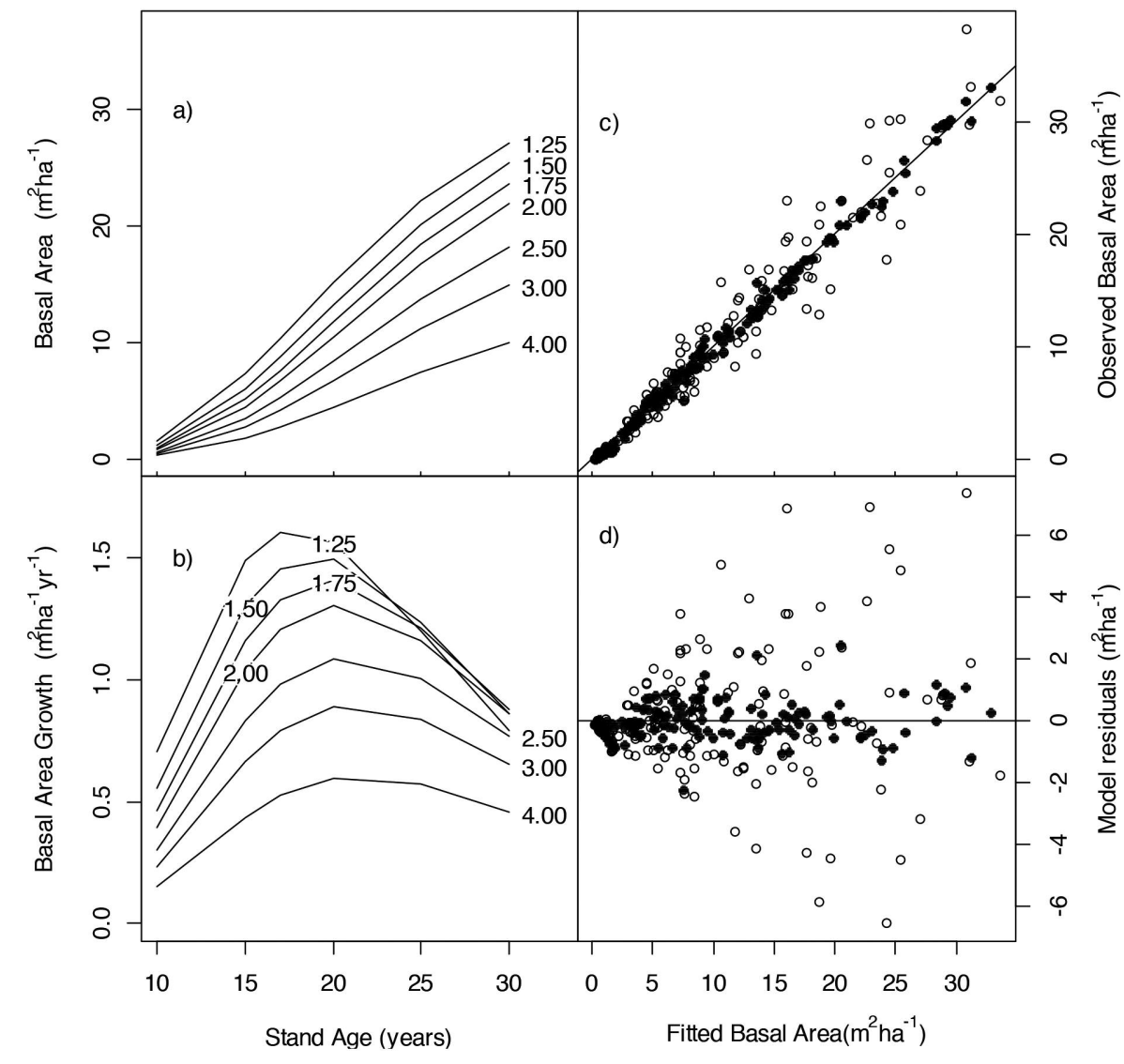

Fig. 4. Modelled basal area (a) using eq. 4 and basal area growth (b) using eq. A1 (Appendix A) versus age for initial spacings from 1.25 to $4.00 \mathrm{~m}$ with $\alpha_{0, s p}=0$ and $H 100_{30}=10.0 \mathrm{~m}$. Observed basal area (c) and model residuals (d) vs fitted basal area with estimated random effects ( $\alpha_{0, s p}$ ) for subplots (closed symbols) and with random effects set to 0 (open symbols).

date has not been large, with a maximum cumulative rate of less than $8 \%$ for the highest initial planting density. Based on the Newton and Weetman (1993) model for relative stand density derived from the self-thinning rule however, the subplots at $1.25 \mathrm{~m}$ spacing were at a relative density of greater than 0.6 for both terrain categories at age 30 . This is above the lower limit of the zone of imminent competition-mortality, indicating that the mortality rate will accelerate at the highest initial planting density in subsequent years. Increases in mortality will have a substantial effect on future tree and stand development.

The observed response to age 30 of tree size and cumulative mortality to density variation quantified in model form in this study contrasts sharply with responses predicted by a stand density management model calibrated with data from managed upland black spruce stands (Newton 2012; model predictions provided by PF Newton, Research Scientist, Canadian Forest Service, February 2016). For the range of nominal initial stem densities in this study (640 to 6400 stems $\mathrm{ha}^{-1}$ ), the range in mean volume per tree at age 30 in the model predictions ( 46.5 to $37.0 \mathrm{dm}^{3}$, respectively) was only
$16 \%$ of the range in the observations $\left(78.9\right.$ to $20.3 \mathrm{dm}^{3}$, respectively). Conversely, the range in cumulative mortality from age 10 to 30 in the model predictions (3.9 to $24.2 \%$, respectively) was more than five times the observed range ( 0.4 to $4.3 \%$, respectively). Essentially, the stand density management model predicted a strong mortality response and weak tree size response to density variation to age 30, opposite of what was observed. Model predictions agreed well with observations at the central initial density of 2500 stems ha $^{-1}$, typical of forest management practice. The possibility that a model calibration weighted to typical forest management densities does not realistically represent the response to broader density variation deserves further research.

Although initial planting density has been found to affect height growth for some species (MacLaren et al. 1995, Curtis 2013), the results of this study showed no evidence of a spacing effect. This is consistent with the generally observed insensitivity of height development to stand density (Lanner 1985). The subplot-to-subplot variation in $\mathrm{H} 100_{30}$ (range of $2.5 \mathrm{~m}$ ) is presumably an indication of site quality variation, likely related to the two site types (upland and transitional) represented in 


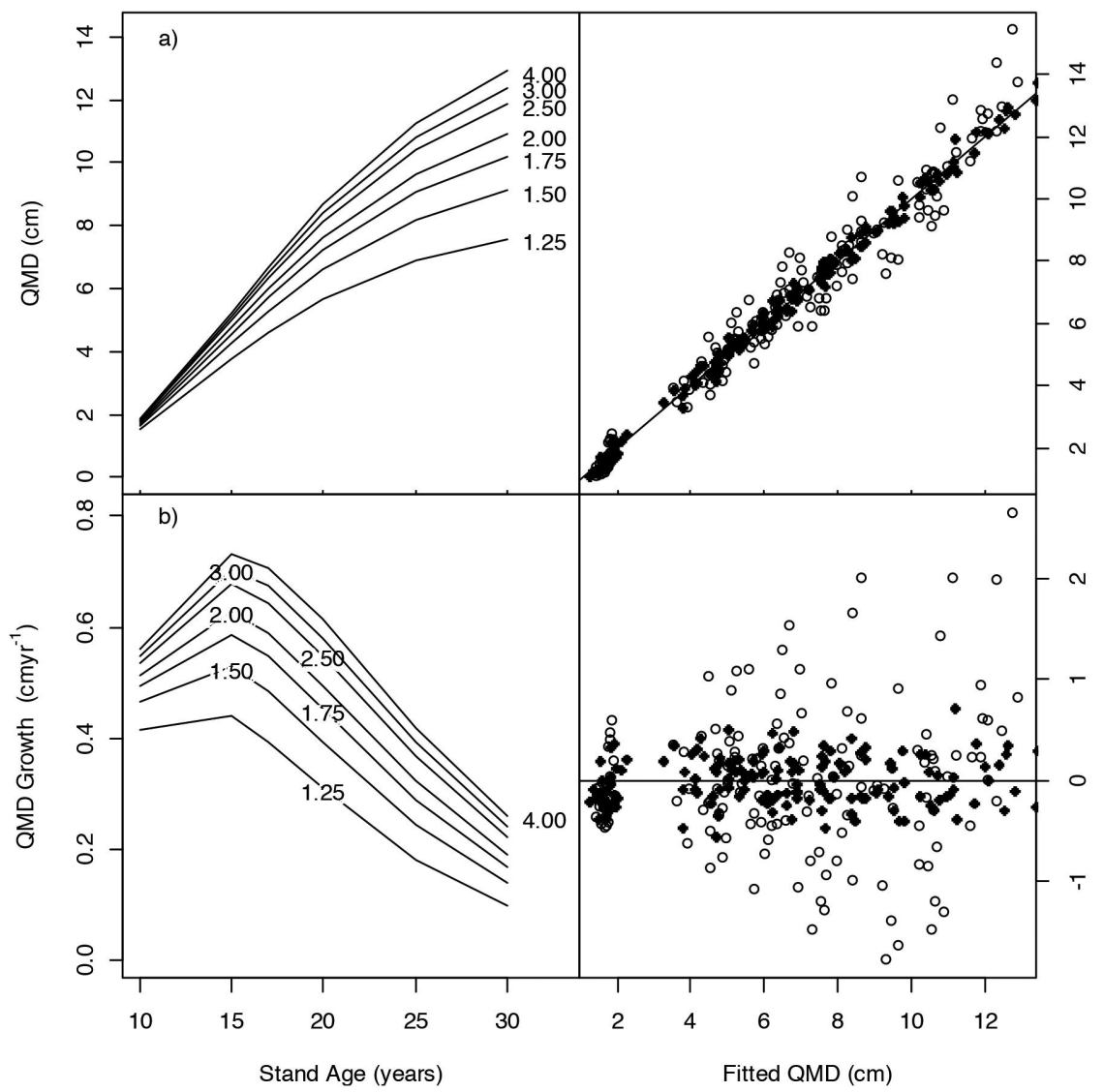

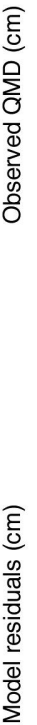

Fig. 5. Modelled $Q M D$ (a) using eq. 5 and $Q M D$ growth (b) using eq. $A 2$ (Appendix $A$ ) versus age for initial spacings from 1.25 to $4.00 \mathrm{~m}$ with $\alpha_{0, s p}=0$ and $H 100_{30}=10.0 \mathrm{~m}$. Observed $Q M D$ (c) and model residuals (d) vs fitted $Q M D$ with estimated random effects $\left[\alpha_{0, s p}\right.$ ) for subplots (closed symbols) and with random effects set to 0 (open symbols).

this study. Consequently, $\mathrm{H}_{100_{30}}$ was used a measure of site index in the analyses, and proved to influence both the asymptote and the curve shape for VOL, BA and $Q M D$.

The descriptive models fitted to the observations suggest that stand development is highly sensitive to site quality since the asymptote and the shape of the curve for total volume and basal area were functions of $H 100_{30}$. A $10 \%$ increase in top height at age 30 results in a $50 \%$ increase in age 30 total volume over a range of spacing, according to the fitted volume model. Although the Chapman-Richards function is biologically plausible, extrapolation of results outside the range of fitting data may be risky. The extrapolation risk is especially high for site quality, since the range of site quality in the observations was limited.

Longer term results (age 37) are available from a black spruce initial planting density experiment near Thunder Bay, Ontario (McLain et al. 1994), but for a narrower range of spacing (i.e., 1.8 to $3.6 \mathrm{~m}$ ). Another spacing experiment in New Brunwick (Matheson and Stewart 1986), encompassed even narrower tree spacing (i.e., 1.1 to $2.3 \mathrm{~m}$ ) with reported results only up to age 14 . These studies are located south of the boreal forest region and experience longer growing seasons compared to the the Kapuskasing trial (Rowe 1972). Nevertheless, tree height values at the New Brunswick study ranged from 4 to $5 \mathrm{~m}$ (age 14) similar to the observed heights at the Kapuskasing trial, and age 37 height values for the Thunder Bay study ranged from 11 to $12 \mathrm{~m}$, similar to the extrapolated heights for the analyzed trial.

However, diameter values for the Kapuskasing trial were on average 2 to $3 \mathrm{~cm}$ less than the observed values in New Brunswick and Thunder Bay for similar ages and initial planting density. This outcome indicates that height development in the boreal is similar to the more southern locations with similar spacings and ages; however, the overall volumetric stand productivity is lower in the boreal. Therefore the Kapuskasing trial is more applicable to the boreal region compared to the other two studies.

The results of this study, which provide a continuous quantification of the tradeoff between individual tree size and stand volume at different spacings, will help forest managers to make decisions about initial planting density for black spruce. The results at age 30 suggest that site occupa- 


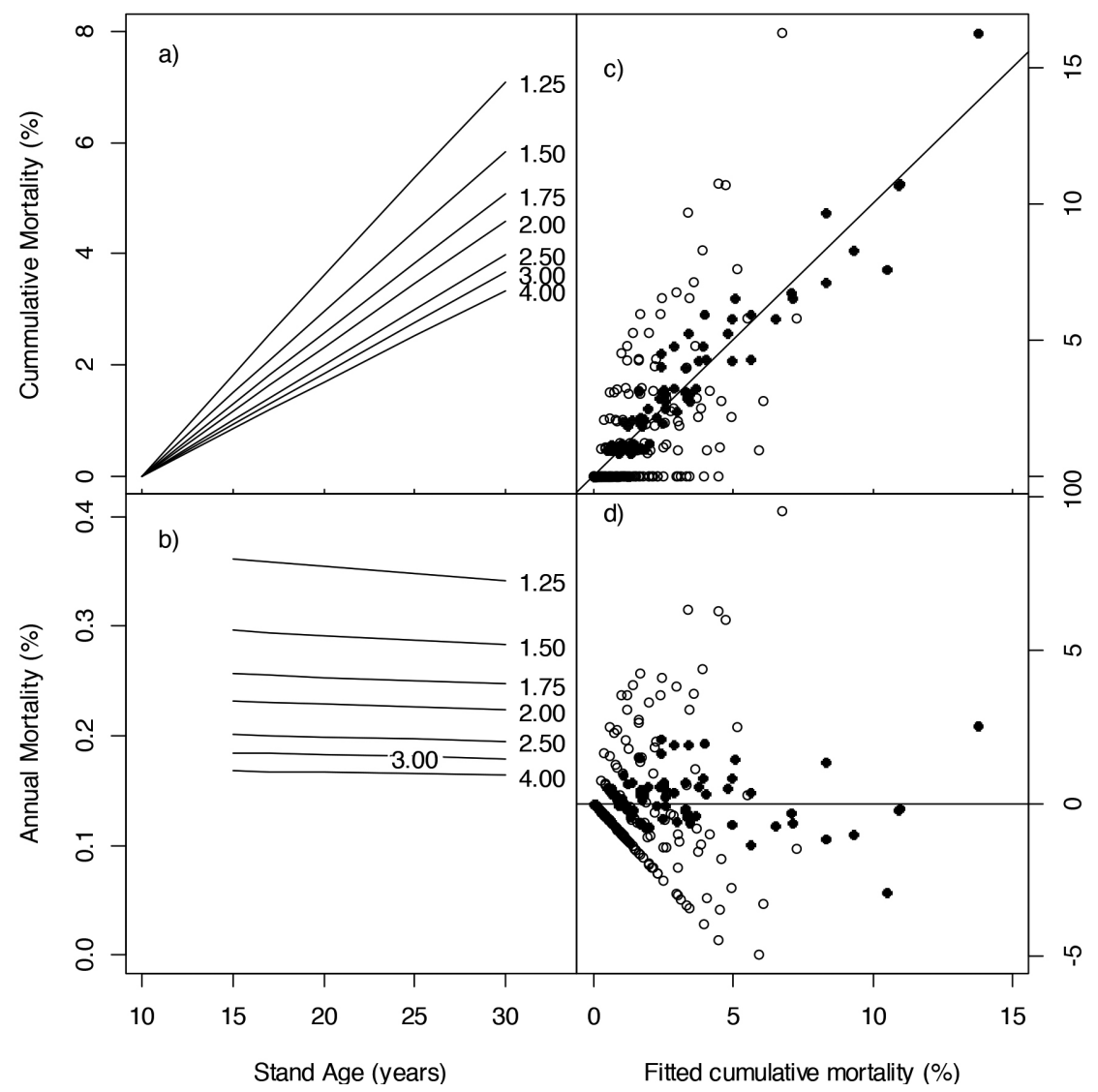

Fig. 6. Modelled cumulative mortality (a) using eq. 6 and annual mortality (b) using eq. $A 3$ (Appendix A) versus age for initial spacings from 1.25 to $4.00 \mathrm{~m}$ with $\alpha_{0, s p}=0$ and $H 100_{30}=10.0 \mathrm{~m}$. Observed cumulative mortality (c) and model residuals (d) vs fitted cumulative mortality with estimated random effects $\left(\alpha_{0, s p}\right)$ for subplots (closed symbols) and with random effects set to 0 (open symbols).

tion, and consequently stand volume development, is reduced when $\mathrm{TPH}_{10}$ is less than about 2000 to $2500 \mathrm{ha}^{-1}$, while $\mathrm{TPH}_{10}$ levels greater than this increasingly restrict tree diameter development. The selection of an optimum level of initial planting density is ultimately an economic decision, and needs to take into account the effects of initial density on planting and carrying costs, future harvest costs, and on timber quality and value. Planned silvicultural treatments, especially thinning, must also be considered in the determination of the optimum initial planting density.

\section{Acknowledgements}

This paper is dedicated to the memory of the late Kent Virgo, Superintendent of Forestry Services for Spruce Falls Power and Paper Company at the time, who was instrumental in making this spacing experiment a reality. We also appreciate the contribution of a number of summer students and technicians in carrying out field measurements over the years. We are especially grateful for the sustained contribution of Mike Adams over the entire course of the experiment for co-ordinating measurements, maintaining records and compiling data. Dr. Peter Newton provided predictions of stand characteristics from a decision-support system for forest desnity management. Mike Hoepting and two anonymous reviewers provided useful comments on drafts of this paper.

\section{References}

Bell, F.W., J. Parton, N. Stocker, D. Joyce, D. Reid, M. Wester, A. Stinson, G. Kayahara and B. Towill. 2008. Developing a silvicultural framework and definitions for use in forest management planning practice. Forest Chron. 84: 678-693.

Burnham, K.P. and D.R. Anderson. 2002. Model selection and multimodel inference: A practical information-theoretic approach, 2nd ed. Springer-Verlag, New York. 488 p.

Curtis, R.O. 2013. True fir spacing and yield trials - 20-year update. USDA For. Ser., Pacific Northwest Research Station. Res. Pap. PNWRP-590. 32 p.

Hall, D.B. and R.L. Bailey. 2001. Modeling and prediction of forest growth variables based on multilevel nonlinear mixed models. For. Sci. 47: 311-321.

Honer, T.G., M.F. Ker, M.F. and I.S. Alemdag. 1983. Metric timber tables for the commercial tree species of central and eastern Canada. Can. Dept. Environ., Can. For. Serv., Fredericton, NB, Inf. Rep. M$\mathrm{X}-140$. 
Lanner, R.M. 1985. On the insensitivity of height growth to spacing. For. Ecol. Manage. 13: 143-148.

MacLaren, J.P., J.C. Grace, M.O. Kimberley, R.L. Knowles and G.G. West. 1995. Height growth of Pinus radiata as affected by stocking. New Zeal. J. For. Sci. 25: 73-90.

Matheson, E.T. and P.R. Stewart. 1986. The effects of spacing and site on planted white and black spruce in northwestern New Brunswick. Can. For. Serv., Fredericton NB, Maritimes Tech. Note No. 149.

McClain, K.M., D.M. Morris, S.C. Hills and L.J. Buse. 1994. The effects of initial spacing on growth and crown development for planted northern conifers: 37-year results. Forest Chron. 70: 174-182.

Monserud, R.A. and H. Sterba. 1999. Modeling individual tree mortality for Austrian forest species. For. Ecol. Manage. 113 109-123.

Newton, P.F. 2012. A decision-support system for forest density management within upland black spruce stand-types. Environ. Modell. Softw. 35: 171-187.

Newton, P.F. and Weetman, G.F. 1993. Stand density management diagrams and their development and utility in black spruce management. Forest. Chron. 69: 421-430.

Newton, P.F. and Weetman, G.F. 1994. Stand density management diagrams for managed black spruce stands. Forest. Chron. 69: 65-74.
Pienaar, L.V. and K.J. Turnbull. 1973. The Chapman-Richards generalization of von Bertalanffy's growth model for basal area growth and yield in even-aged stands. Forest Sci. 19: 2-22.

Plonski, W.L. 1974. Normal yield tables (metric) for major forest species of Ontario. Ontario Ministry of Natural Resources. 40 p.

Pretzsch, H. 2009. Forest Dynamics, Growth and Yield. SpringerVerlag, Berlin. 664 p.

Rowe, J.S. 1972. Forest regions of Canada. Can. Dep. Environ., Can. For. Serv., Publ. No. 1300.

R Core Team (2012). R: A language and environment for statistical computing. R Foundation for Statistical Computing, Vienna, Austria. ISBN 3-900051-07-0, URL http://www.R-project.org/.

Skovsgaard, J.P. and Vanclay, J.K. 2008. Forest site productivity: a review of the evolution of dendrometric concepts for even-aged stands. Forestry 81: 13-31.

Stage A.R. 1975. Prediction of height increment for models of forest growth. US For. Serv. Res. Pap. INT-164.

Taylor, K.C., R.W. Arnup, B.G. Merchant, W.J. Parton and J. Nieppola. 2000. A field guide to forest ecosystems of northeastern Ontario. Ont. Min. Nat. Resour., Northeast Sci. \& Tech. Field Guide FG-001. 


\section{Appendix A}

First derivatives of response variables with respect to $A G E$ for the final fitted models (eq. 4-6) in the text.

eq. $4 \quad \frac{d V O L}{d A G E}$ or $\frac{d B A}{d A G E}=a_{2}\left(a_{0}+b_{0} H 100_{30}\right) \cdot\left(1-\exp \left(b_{1} T P H_{10}\right)\right)$.

$\left(1-\exp \left(\left(a_{1}+b_{3} T P H_{10}\right) A G E\right)\right)^{a_{2}-1} \cdot\left(-\left(a_{1}+b_{3} T P H_{10}\right) \exp \left(\left(a_{1}+b_{3} T P H_{10}\right) A G E\right)\right.$

eq. $5 \quad \frac{d Q M D}{d A G E}=a_{2}\left(a_{0}+b_{0} H 100_{30}\right) \cdot \exp \left(b_{1} T P H_{10}\right) \cdot$

$\left(1-\exp \left(\left(a_{1}+b_{3} T P H_{10}\right) A G E\right)\right)^{a_{2}-1} \cdot\left(-\left(a_{1}+b_{3} T P H_{10}\right) \exp \left(\left(a_{1}+b_{3} T P H_{10}\right) A G E\right)\right.$

eq. $\left.6 \frac{d M O R T}{d A G E}=-100\left(b_{2} T E R R A I N+b_{3} T P H_{10}\right) \cdot\left(\exp \left(b_{2} T E R R A I N+b_{3} T P H_{10}\right)(A G E-10)\right)\right)$ 